\title{
Die vrou in die wetenskap
}

Ons lewe in 'n tyd waarin daar 'n nypende tekort aan opgeleide mannekrag bestaan en daar word al meer na die vrou gekyk om hierdie leemte te help vul. In die wetenskap bly die persentasie dames wat die hoogste vlak bereik, teleurstellend laag. Die sukses van Marie Curie bly die uitsondering en nie die reël nie. Waarom is dit so en kan daar iets aan gedoen word? Antwoorde op hierdie vrae is volop, maar terselfdertyd ook geweldig kompleks.

Alhoewel tradisionele opvattings omtrent die vrou se rol in die samelewing al 'n mate van erosie ondergaan het, oorheers dit nogtans ons hele lewenspatroon. Kom ons kyk na 'n paar van die populêre opvattings, oftewel wanbegrippe, wat gehuldig word:

- Die vrou behoort die totale huishouding te behartig in die huwelik en haar man en kinders by te staan sodat hulle tot hul hoogste potensiaal kan ontwikkel. Dus, 'n aanvullende rol waarin haar eie potensiaal heeltemal buite rekening gelaat word. Al sou sy deeltydse werk doen om die leemte te vul (terloops die wens van die meerderheid gegradueerde getroude moeders') bly dit 'n kompromie. By jong meisies word aanvaarding van hierdie rol gekenmerk deur hul onwilligheid om 'n ambisieuse beroepskeuse te maak omdat dit tog maar tydelik sal wees. ${ }^{2}$

Wessels ${ }^{\prime}$ meen dat dames die tegnologie en wetenskap vermy omdat hulle besef dat hierdie gebiede as loopbaan te veeleisend is om met 'n huwelik en familie te kombineer.

- Die vrou is van nature nie aangelê vir die ingenieurswese en die wetenskap nie. Die biomediese wetenskappe word beskou as 'n uitsondering, maar selfs hier vul dames nogtans 'n lae persentasie van poste. Ten spyte van goeie aanvanklike resultate in die wetenskap en wiskunde op skool, het meisies meestal nie die selfvertroue om hiermee te volhard nie, deels as gevolg van sosiale kondisionering daartoe dat hul later swakker sal vaar (vrees vir mislukking), en deels omdat dit as onvroulik beskou word en sukses op hierdie gebied sosiaal onaanvaarbaar is (vrees vir sukses). ${ }^{2}$ 'n Interessante bevinding $\mathbf{3 . 4}$ is dat meisies op meisieskole konsekwent beter in fisika presteer as meisies op gemengde skole. By meisieskole is daar 'n meer ondersteunende beleid om meisies tot die beste van hul vermoëns te ontwikkel, ${ }^{4}$ maar die swakker prestasie by gemengde skole dui ook daarop dat meisies hier doelbewus onderpresteer ter wille van hulle vroulike beeld by die seuns in hul klas. ${ }^{4}$ Die invloed van hierdie aspek kan nie genoeg beklemtoon word nie. Vakkeuses moet juis in die tienderjare gemaak word wanneer die vroulike identifiseringsproses en die rol van aantreklikheid so belangrik is.

Talle studies is oor verskille in eienskappe tussen die geslagte gedoen en daarvolgens bestaan daar geen bewese verskille wat nie aan omgewingsaspekte toegeskryf kan word nie. 'n Uitsondering is dié van groter aggressiwiteit by mans, wat eerder 'n negatiewe korrelasie met navorsingsvermoë het. ${ }^{4}$

- Die vrou ly aan 'n gebrek aan ambisie. Geen wonder nie! Daar is min voorbeelde van dames wat sukses behaal het in die dubbele rol van beroepsvrou en moeder. Dit is hierdie dubbele rol wat altyd van die vrou vereis word, let wel deur haarself ook, wat 'n groot struikelblok is. Die meeste vroue wat graag wil presteer op beroepsgebied, wil ook goeie moeders wees. Slegs $1 \%$ van gegradueerde getroude dames wil 'n loopbaan teen elke prys hê, dit wil sê hulle is bereid om kinderloos te wees ter wille van hul beroep.'

In die wetenskap word vooruitgang en bevordering gemeet aan 'n volgehoue vloei van publikasies van hoë gehalte. Watter manlike wetenskaplike se ambisie en loopbaan sal nie 'n knou kry nie as hy moontlik van sy $25 \mathrm{e}$ tot $35 \mathrm{e}$ jaar (algemeen beskou as die wetenskaplik produktiefste jare) buite sy beroep moet staan, terwyl hy hom besig hou met huishoudelike take-hoe verantwoordelik en heilig dit ook al geag mag word.

'n Opname van die RGN toon dat dames wat in die wetenskap kwalifiseer, van die mense is wat die minste gemotiveer is wat loopbaangerigtheid betref, juis omdat hulle besef watter prys betaal moet word vir die agterstand wat selfs 'n kort onderbreking in hierdie hoogs kompeterende en snel ontwikkelende veld sal veroorsaak. ${ }^{1}$

Die groter buigsaamheid en verskeidenheid keuses wat die mediese beroep bied (en sekerlik ook die goeie remunerasie), help dan ook dat 'n baie hoë persentasie (meer as 93\%) vroulike medici aktief in hul beroep bly ten spyte van familieverpligtinge. ${ }^{5}$

Tradisionele lewenspatrone en opvattings moes al dikwels die knie buig voor die druk van ekonomiese 
werklikhede. Dit was in oorlogstye, veral in die twee wêreldoorloë, dat die vrou bewys het dat sy letterlik haar man kon staan en verantwoordelikhede kon hanteer wat tradisioneel slegs vir mans gereserveer was. Die gebrek aan vroulike bydraes op wetenskaplike en tegnologiese gebied is egter nie net 'n massiewe verlies aan ontginbare hulpbronne wat die landsekonomie moet verduur nie, maar is 'n ewe drastiese verlies vir die vrou wie se potensiaal op hierdie gebied kunsmatig onderdruk word. Hul toegang tot die onontbeerlike, snelgroeiende en grootste arbeidsmark word hul sodoende ontneem, asook die persoonlike vervulling wat dit meebring. ${ }^{3}$ Selfs al sou daar uiteindelik beroepe buite die wetenskap gekies word, kan ' $n$ mens deesdae slegs baat vind by 'n beter begrip van ons tegnologiese wêreld.

Die finale struikelblok is diskriminasie teen die vrou wanneer sy wel binne die wetenskaplike beroep staan. Bevordering is stadiger, laer poste word oor die algemeen beklee en daar word minder betaal. ${ }^{6}$ In 1965 het dames $7 \%$ van die wetenskaplike en ingenieursarbeidsmag in die VSA uitgemaak; teen 1980 het dit gestyg tot $23 \% .^{5}$ Namate diskriminasie op grond van geslag verminder, sal hierdie persentasie sekerlik toeneem.

Wat moet gedoen word om hierdie saak reg te stel?

- Die samelewing sal oortuig en oorreed moet word om sy tradisionele vooroordeel oor die vrou se rol te bowe te kom. Dit geld beide die man se siening van die vrou en die vrou se siening van haarself. 'n Paar positiewe voorbeelde van suksesvolle, aantreklike en gelukkige beroepsvroue met 'n goed gebalanseerde familielewe sal baie help om die saak te bevorder.

- Werksomstandighede en opvoedkundige bedrywighede sal aangepas moet word om die bestuur van 'n huishouding met kinders op realistiese wyse te akkommodeer en ook so dat beide vader en moeder betrek sal word.

- Diskriminasie op grond van geslag sal moet verdwyn.
Dit is nie dinge wat oornag sal gebeur nie, maar 'n begin moet gemaak word. Daar moet reeds op skoolvlak positiewe insette oor die wetenskap as vak en oor die vrou in die beroepslewe gemaak word. Ouers en werkgewers moet oorreed word om die noodsaaklikheid van veranderde benaderings te aanvaar en uit te leef.

Opsommenderwys kan net herhaal word dat die vraagstuk en die oplossing daarvan uiters kompleks is. Die vrou word uit hierdie besondere arbeidsmark gehou enersyds deur die stigma van onvroulikheid wat kleef aan sukses op dié gebied, en andersyds deur die stigma van haar sogenaamde minderwaardigheid en onvermoë op dié gebied. 'n Bydraende faktor wat ook vir ander beroepe geld, is die probleme verbonde aan die veeleisende dubbele rol van beroepsvrou en moeder.

Die oplossing sal 'n aktiewe nasionale poging vereis; of dit sal waarskynlik geleidelik en vanself ryp gedruk word deur ekonomiese eise; of die vrou sal self deur haar positiewe optrede, ten spyte van die heersende sisteem met sy diskriminerende praktyke, tradisionele opvattings die nek inslaan.

[Opgestel deur Nicoline Basson]

\section{VERWYSINGS}

1. Wessels, Dinah M. (1981). Career orientation and work commitment of university-educated women, Verslag MM-85, Raad vir Geesteswetenskaplike Navorsing.

2. Van Rooyen, J. (1981). women and Careers. For Seminar: Women in management and in professions UNISA.

3. Ferry, G. (1982). How women figure in science. New Scientist 94 (1299) 10-13.

4. Kistiakowsky, V. (1980). Women in Physics: unnecessary, injurious and out of place? Physics Today, 33(2) 32-40.

5. Van Reenen W.M. en Nicol J. (1980). Dames in besit van die graad MBChB(Pret.): 'n Opvolgstudie. Studentediensburo, UP.

6. Garfield, E. (1982). Why aren't there more women in science? Current Contents, No. 17, 5-12. 